\title{
Id, Ego and Superego in the Main Character of Mata di Tanah Melus Novel by Okky Madasari
}

\author{
Yuliana Sari $^{1}$, Sarwiji Suwandi ${ }^{1}$, Nugraheni Eko Wardani ${ }^{1}$ \\ ${ }^{1}$ Postgraduate of Universitas Sebelas Maret \\ yulianasaripenulis@gmail.com
}

\begin{abstract}
The purpose of this research is to explain and describe the form of id, ego, and superego in the main character in the Mata di Tanah Melus novel by Okky Madasari. The method used in this study was a descriptive method with a qualitative approach. The data source in this study was a document in the form of Mata di Tanah Melus novel by Okky Madasari, which was published by Gramedia Pustaka in 2018. The data used in this study were dialogues in the novel. The data analysis technique used in this study was the analysis of documents to find the form of id, ego, and superego in the novel. The results of this study indicate that there were forms of id, ego, and superego in Okky Madasari's Mata di Tanah Melus novel which were reflected by the main character. The forms of id, ego, and superego were found based on Sigmund Freud's personality theory. Through the form of id, ego, and superego, it can be seen how the personality of the main character in the Mata di Tanah Melus novel by Okky Madasari.
\end{abstract}

Keywords : psychoanalysis; id; ego; superego; novels; Mata di Tanah Melus

\section{Introduction}

Literary psychology is a scientific study which is lately very popular among researchers. Psychology is usually used to find out how the personality of a character in a literary work, especially a novel. When the author wrote the novel, he described the character and personality of the character as a psychological activity which was displayed by the appropriate or ideal resolution of the psychology. The author tries to present characters in novels with various types so that literary works will describe the psyche of humans through their characters fictitiously.

This study uses Mata di Tanah Melus novel by Okky Madasari as a data source. The novel was analyzed with psychoanalytic personality theory which was triggered by Sigmund Freud that consists of three aspects, namely id, ego, and superego. Id is a fundamental trait to achieve something, while the ego presents to fulfill the desire of the id. On the other hand, the superego tries to be a determinant of whether something wants to be achieved either by id or ego is worthy to be made or not.

Based on that understanding, the researcher was very interested in studying the novel Mata di Tanah Melus by Okky Madasari using Sigmund Freud's psychoanalytic theory. Mata di Tanah Melus is a novel published by Gramedia Pustaka in 2018 and is Okky's first work aimed at children and is the first story of a series of children's adventures. The researcher chose Mata di Tanah Melus novel to be studied using a literary psychology approach because the novel has psychological aspects. This study aims to describe and explain the personality aspects of the main character in Okky Madasari's Mata di Tanah Melus novel based on Sigmund Freud's personality theory. 


\section{Review of Literature}

Literary psychology is the study of literature which is believed to reflect psychic processes and activities (Minderop, 2016: 54). Research on literature using psychology is done by placing literary works as dynamic subjects. Literary works determine the theory, not the other way around. That is, after reading literature, it will be known which psychological theory is the right one to use.

The relationship between literary work and psychology is so close that it merges and gives birth to literary psychology (Budiantoro \& Mardiantoro, 2016: 47). Therefore, the study of literature using psychology is important to do. This is in accordance with the opinion of Minderop (2016: 53) which states that the literary works of novels, dramas, and poems in modern times are full of psychological elements as manifestations: psychic authors, fictional figures in narration, and readers. In addition, Sidney (in Minderop, 2016: 52) also states that the moral effect of a literary work is psychological literature.

Minderop (2016: 54) reveals that the aim of literary psychology is to understand the psychological aspects contained in literary works. Through the understanding of leaders, for example, the community can understand changes, contradictions and other irregularities that occur in society, especially those related to psychology. Basically, literary psychology gives attention to the mental problems of fictional figures contained in literary works (Ratna, 2011: 343).

One of the literary works that can be studied using literary psychology is a novel. The novel is a long-established prose that presents characters, a series of events, and a structured character. Abrams (1999: 94) reveals that novels (works of fiction) are narrative works which contents do not convey to factual truths, something that really happened.

The study of literature using a psychological approach gets a place in the hearts of researchers, students, and lecturers of literature (Minderop, 2016: 53). Without the presence of literary psychology with a variety of psychological references, the possibility of understanding literature will be lame. One theory that can be used to analyze literary works using a psychological approach is the psychoanalytic theory that was first introduced by Sigmund Freud. This psychoanalytic theory is usually used to analyze the personalities of figures in literary works (novels).

Personality according to Santrock (1988: 435) is a trait that includes thoughts, feelings, and behavior is a characteristic of a person who displays the way he adapted and compromised in life. Whereas according to Freud (Minderop, 2016: 20) behavior is the result of conflict and reconciliation of the personality system. Factors influencing personality are past historical factors and contemporary factors, analogies of innate factors and environmental factors in shaping individual personalities.

According to the psychology point of view developed by Sigmund Freud, the character or human personality is divided into three, namely the id, ego, and superego. These three personality systems are mutually related and form the totality and behavior of humans which is nothing but the product of the interaction of the three. Id is a biological component, ego is a psychological component, while superego is a social component (Corey, 2003: 14).

As stated by Freud, the $i d$ is in the layer of the unconscious soul. The way the id works relates to the principle of pleasure, which is always seeking pleasure and always avoiding inconvenience. According to Corey (2013: 62) the $i d$ is the original system of personality: at birth a person is all $i d$. The $i d$ is the primary source of the psychic energy and the seat of 
instincts. It lacks organization and is blind, demanding, and insistent. Id only arises from pleasure without being realized by values, ethics, and morals. By operating on this principle of pleasure, $i d$ is the source of all psychic energy, namely libido which is essentially sexual.

The ego is the mental part of the human being occupying the area of consciousness. Friest \& Feist (2010: 27) states that the ego is governed by the principle of reality, which seeks to be a substitute for the pleasure principle of id. The ego of the mandate of the id will function as a transactor, executor, organizer, and regulator in managing the tasks of the $i d$ to connect with the real world (Fudyartanta, 2012: 138).

The Superego is the third and final personality system conceptualized by Freud. Superego is a part of the human soul that is produced in response to the influence of parents, teachers, and other authority figures in childhood (Budiantoro \& Mardianto, 2016: 28). According to Hall and Lindzey (1993: 67-68) the three main functions of the superego, among others (1) hinder the impulses of the $i d$, especially the impulses of sexuality and aggressiveness, (2) encourage the ego to replace the goals of reality with goals morality; and (3) teaching perfection. The superego tends to oppose both the $i d$ and the $e g o$, and makes the world in its own image.

The study of literature using literary psychology was at least done by Setyorini (2017), Hilmi, Winarni, \& Rohmadi (2017). The Setyorini (2017) study entitled "Analisis Kepribadian Tokoh Marni Kajian Psikologi Sigmund Freud dalam Novel Entrok Karya Okky Madasari" concluded that the main character in Entrok's novel had personality aspects in the form of $i d$, ego, and superego.

The research conducted by Hilmi, Winarni, \& Rohmadi (2017) entitled "Id, Ego, Superego dana Nilai Pendidikan Karakter dalam Novel Guru Dane Karya Salman Faris" explains the aspects of the id, ego, and superego that all characters in Guru Dane novel. The results of the study indicate that the characters in the Guru Dane novel have fulfilled the psychological aspects in the form of $i d$, ego, and superego.

These studies have similarities, namely to look for personality aspects in the form of $i d$, ego, and superego. The difference is that Setyorini's research focuses on the main characters only, while Hilmi, Winarni, \& Rohmadi's research reveals the personality aspects of all the characters in the Guru Dane novel.

\section{Methodology}

This study aims to describe and explain the form of the personality of the main character in Okky Madasari's Mata di Tanah Melus novel. This study used descriptive qualitative method. Descriptive method is a method of exposure of findings in the form of facts and phenomena obtained based on collected data in the field. In this regard, the steps taken were data collection, data analysis, and presentation of the results of the analysis.

The data sources used in this study were primary data. The primary data source in this study was the novel Mata di Tanah Melus by Okky Madasari, the first print was published by Gramedia Pustaka in 2018. The data collection in this study used techniques; perusal, note, and literature. The perusal technique was done by reading novels repeatedly to get accurate data. The note-taking technique was an advanced technique after the researcher applies the reading technique (Mahsun, 2005: 92-93). This note-taking technique was done by recording important parts. The next was a library technique which was a technique that used written sources to obtain data. 
The steps taken in analysing the data were as follow, (1) read and understand in depth Mata di Tanah Melus novel by Okky Madasari, (2) look for and find out the personality aspects of the main character in Okky Madasari's Mata di Tanah Melus, (3) discuss the personality aspects of the novel to make conclusion.

\section{Discussion}

Sigmund Freud's personality system in Mata di Tanah Melus novel by Okky Madasari covers aspects of the id, ego, and superego. The followings were a classification of the personality aspects of the main character, Matara, in Mata di Tanah Melus novel by Okky Madasari.

\subsection{Id Aspect}

The id aspect perfomed by Matara character was raised from the beginning of the story by the author. This can be seen from the attitude of Matara who really wanted to read stories written by her mother. Matara's desire had a strong reason, namely she considered that she had grown up as a teenager who had the right to know anything written by her mother. This can be seen in the following dialogue;

Mama menulis banyak sekali buku, tapi tak satu pun dari buku itu yang bisa kubaca. Aku sudah ingin membaca buku yang ditulis Mama sejak aku bisa membaca pada usia enam tahun. Mama selalu melarang, buru-buru merebut buku karangannya yang sedang kupegang. "Nanti kamu boleh membacanya saat kamu sudah besar," katanya berulang kali. (p. 13)

The dialogue showed when Matara was eager to read books written by her mother. Matara's id can be seen from her desire which was very strong. However, her wishes cannot be fulfilled because her mother forbaded her.

Furthermore, Matara's id reappeared when she and her mother arrived in Belu for a vacation. Everything began when Matara and her mother separated in quite a long time. Matara got lost in a village that they called Melus Land, where the Melus people lived. The incident made Matara's id often appear. Matara's id showed that she was eager to get out of the Melus Land to meet her mother.

"Tidak...!" aku berseru. Tentu saja aku tidak tahan difitnah seperti itu. "Aku tidak disusupkan. Aku bukan pengintai dan bukan perusak. Aku hanya tersesat. Aku mau pulang. Aku mau bertemu ibuku." Aku sudah ingin menangis lagi. Tapi aku buru-buru menahannya. Malu! Aku tak mau terlihat cengeng di depan begitu banyak orang. Lagi pula, aku tahu itu tak ada gunanya. (p. 89)

The dialogue showed Matara's first time when he felt slandered and wanted to go home. Matara felt she was insecure. She only wanted to be free and met with her mother again.

"Aku ingin bertemu mamaku," kataku pada Mama Atok pagi ini. Seperti biasa, ia selalu datang pagi-pagi ke kamarku dengan membawakanku sarapan. Kali ini ia membawa bubur jagung.

Mama Atok memandangku lekat-lekat. Ia tak menanggapi permintaanku hingga aku terpaksa mengulangnya.

"Kenapa? Kamu tak senang tinggal di sini?” Ia tetap tak menanggapi permintaanku. 
"Bukan soal itu," jawabku. "Tapi aku ingin bertemu mamaku."

Mama Atok menggeleng. "Tak ada yang bisa keluar dari tempat ini. Tapi bangsa

Melus tak akan pernah membunuh anak-anak dan perempuan.” (p. 113)

Matara's id reappeared when one of Melus's people came to her and brought her breakfast. She begged that she could meet with her mother again. However, the Melus people told her that no one could get out of Melus' land.

Matara began to get confused. Finally she asked Atok for help to get out of Melus' land and search for her mother. Atok initially refused, however, because he heard Matara's insistence he finally helped Matara. This can be seen in the following dialogue:

"Jangan sedih, jangan takut," bisiknya.

"Bagaimana aku bisa tidak sedih dan takut? Mereka akan membunuh mamaku. Aku tak akan bisa bertemu lagi dengan mamaku. Aku tak akan lagi punya Mama."

Tangisku semakin menjadi. Kini aku merasa semuanya akan benar nyata terjadi.

"Kita akan cari mamamu."

Bisikan Atok menghentikan tangisku. Aku memandangnya lekat-lekat.

"Hanya kita berdua. Jangan sampai orang lain tahu, termasuk mamaku.

Aku mengangguk tanpa ragu. (p. 116)

Matara's id got stronger when someone was willing to help her. She and Atok finally rushed carefully to get out of Melus's land and search for her mother. However, something bad happened that made them afraid. Even so, Matara did not give up and assured Atok that they would be fine. Matara did not want her plan to meet her mother fail. This can be seen in the following dialogue;

"Atok, ayo kita coba. Kita harus cari jalan. Kamu juga yang selalu bilang, bangsa Melus tak akan membunuh anak-anak dan perempuan. Kita anak-anak, Tok."

Atok seperti menemukan kebenaran dan keberanian dari kata-kataku. Ia berdiri dan keluar dari tempat persembunyiannya. Kami tak lagi bicara apa-apa. Kami terus berlari di bawah guyuran hujan, dalam gelap. Tak ada penanda apa-apa yang kami ikuti. Kami hanya terus berlari, tanpa peduli arah. Aku tak lagi punya kekuatan. Aku yakin, jika aku tak bisa kembali ke kampung Melus, aku akan bertemu Mama. (p. 120).

The dialogue shows that Matara's id worked perfectly. She believed everything she did was the best. She must immediately find her mother no matter what blocked her.

Hurdles after obstacles they went through. After they managed to get through the heavy rain, they finally survived. However, they encountered new obstacles again. Matara and Atok met the Queen of Butterflies. They were forced to enter the house of the Queen of Butterflies. Matara and Atok just obeyed it.

Matara did not want to tarry in the house of the Queen of Butterflies. She wanted to get out and continue looking for her mother. She and Atok tried to escape so they could immediately be free. This can be seen from the following dialogue.

"Kita harus melakukannya, Tok. Kita bisa berenang."

"Tapi itu jurang, dalam sekali. Kita bisa mati. Kita tak tahu ada apa di bawah sana."

"Belum tentu kita mati, Tok. Tapi kalau kita tak melakukannya, sudah pasti kita tak akan bertemu lagi dengan mama kita."

Atok tak berkata apa-apa lagi. Tapi aku tahu dia tak memilih untuk tetap tinggal di sini.

Kami berjalan pelan-pelan mendekati tepian sungai. (p. 149). 
The dialogue showed the sincerity of Matara's id to come out of the Queen of Butterfly's house. She had strong faith and determination to immediately meet with her mother.

After escaping from the Butterfly kingdom, Matara and Atok continued the journey. They jumped into the river and laid on the banks of the river. They were surprised to find many crocodiles in the river. Again they were faced with something terrible.

Semakin laki-laki itu mendekat, aku girang. Sementara Atok hanya diam dan justru terlihat makin tegang. Kini laki-laki itu begitu dekat, membuatku bisa melihatnya dengan utuh. Ia bukan manusia. Ia buaya. Ia manusia yang separuh tubuhnya buaya. Ia buaya yang separuh tubuhnya manusia. Setelah bertemu dengan Ratu Kupu-kupu, kini aku harus bertemu dengan manusia buaya. Aku benar-benar ingin segera bertemu Mama, pulang ke Jakarta, kembali ke kamarku. (p. 154)

The dialogue showed the shock of Matara when she saw a crocodile man. Matara didn't want to do much, he just wanted to go home and meet her mother. The dialogue also shows the Matara's id that appeared consistently.

Matara's struggle was over. She found her mother after going through a long and terrible road. Matara's id which appeared repeatedly yielded results. She had met her mother. This can be seen in the following dialogue;

Dalam suasana yang kian gelap, samar-samar terlihat ada cahaya terang. Kami berjalan menuju sumber cahaya itu. Ternyata cahaya itu berasal dari api unggun.

Beberapa orang duduk mengelilingi api unggun itu. Aku dan Atok mendekati mereka. Kami ingin beristirahat di tempat terang sambil menghangatkan badan.

"Mata! Matara!"

Ada Mama!

Mama ternyata ada di antara orang-orang yang duduk mengelilingi api unggun itu. Aku langsung lari dan menjatuhkan diri dalam pelukannya. Kami berpelukan lama dan erat sekali. Tanpa aku sadari air mata mengalir di pipiku. Aku tak mau lagi berpisah dari mamaku. (pp. 165-166)

The dialogue showed that the Matara's id raised by the author can be fulfilled even though Matara must pass various obstacles. Matara was depicted very emotional in expressing her happiness. She never wants to separate from her mother again any more.

\subsection{Ego Aspects}

Matara was a little girl who also had an ego like other people in general. Matara's ego appeared when he could not get what he wanted. Matara's ego first appeared when she wanted to go to her new friend's house in Belu. Her name is Tania, a friend of Matara. Tania had told Matara that her house was very far away. But Matara continued to insist going on to Tania's house. This can be seen in the following dialogue;

Aku tak lagi bertanya. Aku mulai kesal pada Tania. Kata-kataanya tak bisa dipercaya. Dia juga sudah tak peduli aku kecapekan dan kepanasan, malah semakin cepat saja dia berjalan sambil tertawa-tawa. Tapi kemudian aku juga menyalahkan diriku sendiri. Kenapa aku mau ke rumah Tania, padahal sudah jelas-jelas dia bilang rumahnya jauh dan aku harus jalan kaki. Kini aku kesal pada diriku sendiri. Capek, gerah, haus, mau 
marah tapi tidak tahu harus marah pada siapa, ingin menangis tapi tahu bahwa itu tak ada gunanya. (p. 48)

The dialogue shows Matara's regret for insisting on going to Tania's house. Matara did not listen to Tania's words saying that her house was far away. She still insisted going on to Tania's house. Finally in the middle of the trip she felt tired and wanted to return. Matara's ego was very clear.

Furthermore, Matara's ego appeared many times when she separated from her mother and was in the land of Melus. After her raising desire to escape to look for her mother, Matara repeatedly forced herself to get out of the land of Melus. This can be seen in the following dialogue;

"Itu mamaku," kataku pelan sambil melangkah keluar dari tempat persembunyian kami. Baru satu-dua langkah, Atok buru-buru menarik dan menahanku untuk tetap di tempat. Aku meronta. Satu-satunya yang kuinginkan sekarang adalah kembali ke Mama, bukan malah bersama orag-orang asing ini. Empat kawan Atok kini ikut menahanku. Dua anak memegang tangan, dua anak memegang kaki, satu anak membekap mulutku dengan tangannya. Aku terus berusaha melepaskan diri dan berteriak sekerasnya. Tapi sia-sia. Aku tidak bisa melawan lima anak ini. (p. 107)

The dialogue showed that Matara was eager to meet her mother. Matara's ego appeared when she saw her mother being there with strangers too. She was very anxious to meet her mother, but she was detained by Atok and his friends. Matara tried to break away, but still failed. Her efforts are in vain. Atok's mom said that she would not be able to meet her mother. People who have entered the land of Melus will not be able to get out. This can be seen in the following dialogue;

Mama Atok menggeleng. "Tak ada yang bisa keluar dari tempat ini. Tapi bangsa Melus tak akan pernah membunuh anak-anak dan perempuan.

Lagi-lagi ia mengulang hal yang sudah berkai-kali aku dengar. Bahwa Bangsa Melus tak akan membunuh anak-anak dan perempuan.

"Itu artiya aku tak akan bisa bertemu mamaku lagi?" Aku mulai menangis.

Mama Atok mendekatiku lalu mengusap dahiku. "Lihat, mamamu ada di sini. Keluargamu ada di sini. Kamu orang Melus sekarang.” (p. 114)

The dialogue showed that Matara was so disappointed that she could not meet with her mother. Matara's ego appeared when she intended to invite Atok to look for her mother. Until Atok was willing and they faced a danger, a long journey from Melus' land to search for her mother was not overwhelmed by a number of terrible events. Matara and Atok can pass it all. After they managed to escape from various obstacles, Atok invited Matara to return to Melus' land. However, Matara who was so hard still did not want to and wanted to continue the journey to find her mother. This can be seen in the following dialogue;

"Aku harus mencari mamaku, Tok," kataku setelah ia selesai berenang.

"Kita harus pulang dulu ke kampung Melus," kata Atok. "Kita harus meminta izin kepada Ema Nain dan Maun Iso."

"Kalau tidak diizinkan?"

"Ya kita harus menurut."

"Tok!" 
"Memang harus seperti itu. Kita masih diberi perlindungan sehingga bisa pulang dengan selamat. Kita harus menurut apa kata Ema Nain."

Aku mengikuti langkah Atok dengan terpaksa. Aku tak punya pilihan lain. Aku tak tahu arah. Dan aku percaya, hanya dengan bantuan Atok aku bisa kembali bertemu Mama. (p. 164)

The dialogue showed Matara's unwillingness to return to Melus village. She must continue the journey to find her mother. However, Matara had no other choice. She was forced to follow Atok's wish to return to Melus village. However, Matara remained confident and believed that she could meet her mother by Atok's help.

Matara's ego reappeared when she found her mother. Her mother was with a group of scientists who were looking for information about the Melus nation. Matara was happy. She also quickly told Atok to go home. She already felt enough to get help from Atok. This can be seen in the following dialogue;

"Kamu tak mau pulang, Tok?"

"Aku mau pulang. Tapi aku tak akan bisa sampai jika bersama mereka."

"Ya sudah, kamu pulang saja. Mamamu pasti kebingungan mencari kamu. Aku sudah bertemu mamaku. Kamu pulang saja." (p. 170)

This dialogue showed Matara tone displayed. In fact it was a form of Matara's gratitude to Atok because he had already helped her finding her mother. Matara did not want Atok to be involved further. She asked Atok to come back home because Atok had to go home. Matara also wanted to go back with her mother. She wanted to meet her father. This was seen in the following dialogue;

"Kita pulang ke rumah, Ma?" tanyaku.

"Kamu mau pulang ke rumah?" Mama malah balik bertanya.

"Iya, mau ketemu Papa."

Mama tak berkata apa-apa lagi. Ia hanya mencium keningku dan memelukku kian erat.

Ah, orang dewasa memang selalu tak pernah punya jawaban untuk pertanyaan sederhana. (p. 187)

The dialogue showed Matara's happiness because she had returned to her mother. She also wanted to go home to meet Papa. Although she was a little disappointed because her mother did not answer a simple question, however she was happy to be able to return and would return to Jakarta.

\subsection{Superego Aspect}

The author described Matara as a figure full of ambition and hard work. All that Matara wanted must be achieved including her desire to find her mother. However, the author also described Matara as a good character, willing to yield, and merciful. This was seen when Matara always listened and obeyed what was ordered by her parents. Matara complied with her mother when her mother forbade her reading books written by her mother because Matara was not mature enough for reading such books. Matara's kindness was also seen when she met Tania in Belu. She invited Tania to play even though they had just met and just got to know each other. Matara did not hesitate to invite Tania to visit Tania's house. Even Matara understood when Tania wanted to buy an ice cream but she did not have the money to buy it. 
Finally Matara bought Tania an ice cream. Matara's kindness was seen in the following dialogue;

Kini kami sudah berada di luar pasar. Tania terus berjalan menyusuri jalan raya hingga kemudian berhenti di toko yang menjual es krim. Dia memandangiku tanpa bicara apaapa. Tentu saja aku paham apa maksudnya. Kubeli dua es krim dengan uang yang tadi diberikan Mama. (p. 46).

The dialogue shows when Matara bought an ice cream for Tania. Without reluctance, Matara immediately understood that Tania really wanted ice cream. With great heart Matara bought him for Tania.

The superego character of Matara in the Mata di Tanah Melus was described by the author in a straightforward manner. Matara's superego character was seen in the decisions taken by Matara while struggling to get out of Melus land and find her mother. This can be seen in the following dialogue;

"Kamu tidak mau kami semua mati?" Atok bertanya dengan suara pelan.

Aku menggeleng.

"Kamu tidak mau kan orang Melus mati semua?" ia kembali bertanya.

Lagi-lagi aku menggeleng.

"Kamu juga tidak mau kan melihat kampung kami, seluruh wilayah kami, hancur?"

Tentu saja tidak. Aku pun kembali menggeleng dengan penuh keyakinan. (pp. 107108)

The dialogue showed that Matara succumbed to Atok and her friends. She put aside her ego to meet his mother who was already in front of her eyes. She preferred to protect Atok and other Melus people from the threat of bad people. Matara understood the position of the Melus nation so that she would not let the Melus people hurt. This can be seen in the following dialogue;

"Kamu percaya kami, kan?" ia kembali bertanya.

Aku mengangguk.

"Kami juga bisa percaya kamu, kan?"

Aku kembali mengangguk. Dalam hati aku berjanji untuk tidak membuat mereka celaka, apalagi sampai terbunuh. (p. 108)

The dialogue showed Matara's courage and conviction to protect the Melus nation. The good side of Matara was seen in the conversation. Even though she could escape and meet her mother. However, Matara did not do that to save the Melus people.

Matara's efforts to meet his mother grew stronger. She invited Atok to help her finding her mother. It also shows the aspect of the Matara's superego. Matara tried to convince Atok to be willing to help her. Her efforts were not in vain. Atok was willing to help her. Their journey began by venturing out the land of Melus. With great caution, Matara and Atok moved stealthily so that no one knew their departure. Finally they could get out, but there were many obstacles that must be passed ahead. Matara as a brave and hardworking girl, she tried to calm down and convince Atok that they would survive. This can be seen in the following dialogue;

"Kita tak akan mati di sini, Tok," bisikku. "Kita harus keluar. Kita harus cari jalan." 
"Pulang! Kita bisa pulang ke kampung Melus," jawabku yakin. "Kita belum jauh dari rumah dan aku masih ingat jalannya." (p. 119)

The dialogue showed Matara's tranquillity and non-emotional nature. Even though she was facing danger, Matara was not nervous or scared. She tried as calmly as possible so that Atok would not be afraid.

Matara was a brave girl. This was proven when she and Atok got lost and entered the kingdom of butterflies. She did not give up. Matara tried her best to get out of the place as much as possible. She was sad to hear the story of the Queen of Butterflies, but she was also aware that they had to go on to complete their plan. This can be seen in the following dialogue;

"Aaah kalian... Kalian tidak mau menemaniku," seru Ratu Kupu-kupu dengan nada manja.

"Maafkan aku," jawabku dengan lembut. "Tapi seperti katamu, setiap makhluk punya tugas dari semesta. Tugas kami bukan di sini." (p. 146)

The dialogue showed Matara's gentleness when trying to answer the words of the Queen of Butterflies. She was very calm; carefully she did not want to hurt the Queen of Butterflies. Matara was indeed a very good and caring girl about the surrounding creatures. This can be seen in the following dialogue;

"Mereka mau menangkap buaya, Tok," kataku sambil berjalan.

"Sudah dari dulu," kata Atok. "Itulah sebabnya semakin jarang kita lihat buaya. Semua dibunuh, diambil mereka."

"Kalian betul menyembah buaya, Tok?"

"Kami menyembah banyak hal. Kami menyembah semua kekuatan alam.

"Apakah buaya-buaya yang kita lihat tadi akan mati semua, Tok?"

Atok tiba-tiba menghentikan langkah. Ia seperti teringat sesuatu.

"Kita harus menyelamatkan Dewa Buaya!" (p.159)

The dialogue showed Matara's concern for the crocodile so that Matara asked Atok whether the crocodiles would die. Atok realized something and invited Matara to return to save Crocodile King.

Matara's superego form reappeared when she and Mama and the group arrived in Melus village and wanted to escape. She gave a signal to run. When running, he heard someone call her name. It was Atok. However, Matara did not want Atok to be in danger so she told Atok to go home. This can be seen in the following dialogue;

“Mata!" Suara Atok mengagetkanku. Aku segera menengok ke belakang. Ternyata benar, itu Atok. Atok ikut lari bersama kami. Bukankah ini akan membahayakan dirinya?

"Pulang, Tok! Pulang!" seruku pada Atok. (p. 184)

The dialogue shows Matara's concern for Atok. She worried that Atok would be in danger. Therefore, Matara told Atok to go home. Matara was indeed a kind and loving child. It didn't take long for Matara to feel close to Atok. Until when they had to separate, Matara gave a sweet farewell.

Aku berjalan mendekati Atok. Aku jabat tangannya. Aku peluk dia dengan erat.

"Kita tak bisa bertemu lagi, Tok?" tanyaku. 
"Semua bisa terjadi di masa depan."

"Datanglah ke rumahku, Tok. Di Jakarta."

"Jakarta?" tanya Atok.

Kami berdua tertawa. Entah kenapa kini aku juga merasa lucu dan bodoh setiap kali menyebut nama Jakarta. (p. 186)

The dialogue showed Matara and Atok's happiness. They parted in a good way. They love each other. Matara and Atok were good friends. This showed the superego aspect in Matara appeared and showed Matara's good impression towards Atok.

\section{Conclusion}

Based on the data analysis that has been done, the aspects of personalities based on Sigmund Freud's personality theory were found in the main character, Matara. The id aspect contained in Matara's character was described by the author as a person who had strong determination. Matara's most prominent desire along the storyline was to meet her mother. However she must be able to return to her mother. This desire made Matara do and experience many unexpected things. The ego aspect of Matara's character was described by the author when she forced her will to be able to meet her mother. This made Matara violate things that should not be violated. In fact, many people forbade Matara to continue her intentions, but she insisted and remained on her goal. The superego aspect was described in the Matara character by the author through the nature and attitude of Matara. The author tried to show Matara's good sides behind her very strong determination and hard work.

\section{References}

Corey, G. (2013). Theory and Practice of Counseling and Psychotherapy. USA: Brooks/Cole Cangange Learning.

Feist, J. \& Feist, G.J. (2010). Teori Kepribadian: Theories of Personality (Terj. Hendriatno). Jakarta: Salemba Humanika.

Furdyartanta. 2012. Psikologi Kepribadian. Yogyakarta: Pustaka Pelajar.

Hall, C.S. \& Lindzey, G. (1993). Teori-teori Psikodinamik (Klinis) Freud, Erikson, Jung, Adler, Fromm, Horney, Sullivan. Yogyakarta: Kanisius.

Hilmi, Winarni, \& Rohmadi. 2017. "Id, Ego, Superego dan Nilai Pendidikan Karakter dalam Novel Guru Dane Karya Salman Faris”. Jurnal Aksara. 2(1). pp 24-31

Madasari, Okky. 2018. Mata di Tanah Melus. Jakarta: Gramedia Pustaka Utama.

Mahsun. (2005). Metode Penelitian Bahasa. Jakarta: PT Raja Grafindo Persada.

Ratna, N.K. (2011). Teori, Metode, dan Teknik Penelitian Sastra dari Strkturalisme Hingga Postrukturalisme Perspektif Wacana Naratif. Yogyakarta: Pustaka Pelajar.

Santrock, J.W. 1988. Psychology; Introduction. Iowa, WB.

Setyorini, R. (2017). "Analisis Kepribadian Tokoh Marni Kajian Psikologi Sigmund Freud dalam Novel Entrok Karya Okky Madasari”. Jurnal Kajian Linguistik dan Bahasa. 2(1). pp 12-24. 